\title{
Binding of extracellular matrix proteins to the surface of anaerobic bacteria
}

\author{
I. SZÖKE, C. PASCU*, E. NAGY, Å. LJUNG* and T. WADSTRÖM* \\ Department of Clinical Microbiology, Albert Szent-Györgyi Medical University, Szeged, Hungary and \\ * Department of Medical Microbiology, University of Lund, Sweden
}

\begin{abstract}
The binding of fibronectin, vitronectin, collagen and sialoprotein to 65 anaerobic strains was investigated by means of latex agglutination tests. The binding of fibronectin, collagen and lactoferrin to the same strains was also tested by means of ${ }^{125}$ I-labelled proteins. The strains were isolated from abdominal infections $(55 \%)$, from the faeces of healthy subjects $(29 \%)$ or from the depths of tonsils removed at tonsillectomy (16\%). The binding of fibronectin and collagen to Bacteroides fragilis strains, tested by the latex agglutination assay, was stronger than their binding to other species. The vitronectin binding of the strains was less common, but was always accompanied by fibronectin binding. Binding to fibronectin-coated beads was inhibited by pre-incubation of the bacterial cells with soluble fibronectin and by heat or protease treatment of the bacterial suspension. No inhibition of the binding was observed with carbohydrates. None of the 65 strains exhibited any binding to fetuin or asialofetuin; $8 \%$ of the strains had a binding site for mucin. The binding to mucin-coated beads was inhibited by preincubation of the cells with mucin. The radiolabelling method indicated a low binding to ${ }^{125}$ I-fibronectin. The binding of ${ }^{125}$ I-collagen-I and ${ }^{125}$ I-lactoferrin was higher for the anaerobic strains tested.
\end{abstract}

\section{Introduction}

Different species of the genus Bacteroides are predominant in the human intestinal flora. The species most frequently isolated from faecal samples are $B$. vulgatus and $B$. thetaiotaomicron, whereas $B$. fragilis is the most common anaerobic pathogen in intra-abdominal and pelvic infections [1]. The clinical importance of $B$. fragilis in human anaerobic infections is well known, and the available evidence points to the existence of particular properties in the pathogenicity of this species. Recent studies have demonstrated that the capsule is an important virulence factor in $B$. fragilis strains [2,3]. Pruzzo et al. [4] have shown the ability of pilate $B$. fragilis isolates to agglutinate erythrocytes and to adhere to epithelial and human cells. The adherence of $B$. fragilis and related species to extracellular matrix (ECM) proteins such as fibronectin, vitronectin and laminin has also been proposed as a virulence factor $[5,6]$.

The process of bacterial adherence depends on a recognition system whereby bacterial surface ligands

Received 13 Dec. 1995; accepted 4 March 1996.

Corresponding author: Professor E. Nagy. bind to a quasi-specific host cell receptor (ECM components) [7]. However, the majority of bacterial pathogens remain localised on the extracellular host surface after attachment.

In recent years, much information has been accumulated about the nature of the ECM constituents. These components can be arranged into four major families: (a) collagens of several different types, (b) elastins, (c) proteoglycans (e.g. heparan sulphate and dermatan sulphate) and (d) structural or connective tissue glycoproteins such as fibronectin, laminin, thrombospondin and vitronectin [8]. Some pathogens colonising various mucosal surfaces bind to sialic acid residues in mucins and to cell surface glycoproteins and glycolipids [9].

Like most other organisms, bacteria require iron for cellular functions. Human and animal hosts provide an environment in which the availability of iron is limited. The majority of iron in man is bound to iron-binding proteins such as lactoferrin and transferrin [10]. Lactoferrin is present in gastrointestinal mucosal surface secretion.

Several bacterial pathogens that colonise epithelial 
cells are known to possess surface-associated haemagglutinins produced under appropriate growth conditions in vitro. As erythrocytes and epithelial cells share similar glycoconjugate surface structures, many of these putative tissue cell adhesins can be assayed by simple haemagglutination techniques [11].

The present study examined the binding of different ECM proteins to a collection of anaerobic bacteria originating from various infective processes, or from the stools of healthy individuals. For some strains, haemagglutination was also examined, as were the surface structures of the bacteria by electron microscopy.

\section{Materials and methods}

\section{Chemicals}

Vitronectin and fibronectin were purified from human plasma by the method of Vuento et al. [12]. A collagen preparation (Vitrogen $100^{\mathrm{R}}$, containing type-I $95 \%$ and type-III 5\% collagen, lot no. $87 \mathrm{H} 183$ ) was purchased from Collagen Corporation (Paolo Alto, CA, USA). Collagen type-I (Sigma) was also tested. Pronase E, proteinase $\mathrm{K}$, trypsin, ovalbumin, fetuin, asialofetuin, D-mannose, L-fucose and mucin (Sigma M1778, Lot $112 \mathrm{H} 7025$ ) were purchased from Sigma. Bovine serum albumin (BSA) was obtained from Boehringer Mannheim $\mathrm{GmbH}$. Iodobeads were from Pierce Chemical Company (USA), and latex beads $(0.8 \mu \mathrm{m}$ diameter $)$ from Difco Laboratories. Carboxy-modified latex beads $(0.499 \mu \mathrm{m}$ diameter) were obtained from Seradyn (Indianapolis, USA). Merthiolate was from Kebo Lab. AB, Stockholm, Sweden.

\section{Culture media}

Growth conditions may affect the binding of ECM proteins such as fibronectin and collagen-I to bacterial cells [9]. Accordingly, for variation of growth conditions, anaerobic strains were cultured on peptone yeast extract or on brain-heart infusion agar supplemented with horse blood 5\%. Brain-heart infusion broth and Wilkins-Chalgren broth were used in parallel. The bacteria were incubated for $48 \mathrm{~h}$ in an anaerobic jar at $37^{\circ} \mathrm{C}$ or at $30^{\circ} \mathrm{C}$.

\section{Bacterial strains}

The following strains were examined: $21 \mathrm{~B}$. fragilis and 15 other Bacteroides species isolated from materials obtained at abdominal surgery; 13 strains of B. fragilis and six of other Bacteroides species from faecal samples from healthy subjects; 10 different anaerobic strains (Fusobacterium nucleatum two strains, Peptostreptococcus prevotii, three strains and Prevotella corporis, two strains) from tonsils removed at tonsillectomy; and three Clostridium difficule strains. Staphylococcus aureus Cowan I, S. haemolyticus E
2498 and $S$. haemolyticus SM 131 were used as positive controls, and $S$. saprophyticus TW 111 and $S$. epidermidis 3380 as negative controls for latex agglutination assays. Helicobacter pylori NCTC 11637 was the positive control for the haemagglutination assay and for the particle agglutination assay (PAA) with fetuin- and asialofetuin-coated beads.

\section{Preparation of latex reagents}

Latex particles coated with different proteins were prepared according to the method of Naidu et al. [9]. Briefly, $1 \mathrm{ml}$ of latex particle suspension $(0.8 \mu \mathrm{m}$ diameter) was mixed with $3 \mathrm{ml}$ of $0.17 \mathrm{M}$ glycine$\mathrm{NaOH}$ buffer ( $\mathrm{pH}$ 8.2) and centrifuged at $4500 \mathrm{~g}$ for $5 \mathrm{~min}$, and the pellets were resuspended in $3 \mathrm{ml}$ of the same buffer. Highly purified protein $(100 \mu \mathrm{g})$ was added, and the mixtures were kept at $30^{\circ} \mathrm{C}$ for $12 \mathrm{~h}$ on a horizontal shaker at $50 \mathrm{rpm}$. The mixtures were centrifuged at $9200 \mathrm{~g}$ for $5 \mathrm{~min}$ at $20^{\circ} \mathrm{C}$, and the supernates were discarded. The pellet was resuspended in $2 \mathrm{ml}$ of the glycine buffer containing merthiolate $0.01 \%$ and BSA $0.05 \%$ and kept at $4^{\circ} \mathrm{C}$ for $12 \mathrm{~h}$.

The fetuin- and asialofetuin-coated beads were prepared with $100 \mu \mathrm{l}$ of carboxy-modified latex $(0.8 \mu \mathrm{m})$ particles (CML), which were washed twice with $0.1 \mathrm{M}$ phosphate buffer $(\mathrm{pH} 8.1)$ and suspended and incubated overnight at $4^{\circ} \mathrm{C}$ in $2 \mathrm{ml}$ of phosphate buffer containing $4 \mathrm{mg}$ of 1-ethyl-3-(3-dimethylaminopropyl)carbodiimide. The suspension was centrifuged $\left(1200 \mathrm{~g}, 10 \mathrm{~min}, 4^{\circ} \mathrm{C}\right)$, and the particles were suspended in phosphate buffer containing fetuin or asialofetuin $1 \mathrm{mg} / \mathrm{ml}$ and incubated overnight at $4^{\circ} \mathrm{C}$. The suspensions were centrifuged $(12000 \mathrm{~g}, 10 \mathrm{~min}$, $4{ }^{\circ} \mathrm{C}$ ), and the protein-coated CML particles were washed four times with phosphate buffer and suspended in the same buffer to a final concentration of $1 \%$ total beads, and stored at $4^{\circ} \mathrm{C}$ until used.

\section{Particle agglutination assay}

The 65 strains were grown on various media for $48 \mathrm{~h}$. Bacterial colonies were suspended and washed once in $0.02 \mathrm{M}$ potassium phosphate buffer ( $\mathrm{pH} 6.8$ ). Bacterial cells were resuspended in the same buffer to $c$. OD 1 at $540 \mathrm{~nm}$ and immediately tested for PAA [9]. The strains were tested for auto-aggregation by mixing one drop of phosphate buffer and one drop of bacterial cell suspension. Latex beads coated with BSA were also tested as a negative control.

\section{Heat treatment and proteolytic digestion}

For enzyme treatment, bacteria were washed twice in PBS, and the cell density was adjusted to OD 1 . Proteinase $\mathrm{K}$ and pronase $\mathrm{E}$ were dissolved $(1 \mathrm{mg} / \mathrm{ml})$ in PBS ( $\mathrm{pH}$ 7.2) and trypsin in PBSA ( $\mathrm{pH}$ 7.2). Bacterial suspensions and these enzyme solutions were mixed (1:1). 
For heat treatment, bacteria were washed twice in PBS, the concentration of bacteria was adjusted to OD 1 , and they were incubated in a waterbath at $40^{\circ} \mathrm{C}$, $60^{\circ} \mathrm{C}, 80^{\circ} \mathrm{C}$ or $100^{\circ} \mathrm{C}$ for $20 \mathrm{~min}$.

\section{Particle agglutination inhibition assay}

One hundred $\mu \mathrm{l}$ of inhibitor (fibronectin, $0.1 \mathrm{M} \mathrm{D}$ galactose, D-glucose, L-fucose, N-acetylgalactosamine or mucin) were pre-incubated with an equal volume of bacterial cell suspension for $30 \mathrm{~min}$ at $20^{\circ} \mathrm{C}$ and then mixed with the PAA reagents. Potassium phosphate buffer ( $\mathrm{pH}$ 6.8) was used as a negative control.

\section{Haemagglutination and haemagglutination inhibition assay}

Harvested bacterial cells were suspended in PBS (pH 7.2) to a final colony count of $10^{9}$ cells $/ \mathrm{ml}$. Equal volumes $(50 \mu \mathrm{l})$ of a bacterial suspension in PBS and a $1 \%$ erythrocyte suspension were mixed in the wells of a microtitration plate and allowed to settle for $1-2 \mathrm{~h}$ at $20^{\circ} \mathrm{C}$. PBS was used as a negative control.

For the haemagglutination inhibition assay, the bacterial cell suspensions were diluted with PBS to give 4 HAU (haemagglutinating units). The solutions of inhibitors were also prepared in PBS ( $\mathrm{pH}$ 7.2) at concentrations of $1 \mathrm{mg} / \mathrm{ml}$ or $2.5 \mathrm{mg} / \mathrm{ml}$. Inhibition tests were performed in the wells of a microtitration plate with erythrocyte $1 \%$ suspensions. Bacterial cell suspensions $(50 \mu \mathrm{l})$ were mixed with $30 \mu \mathrm{l}$ of inhibitor solution for $1 \mathrm{~h} ; 50 \mu \mathrm{l}$ of erythrocyte suspension were then added, and the suspension was allowed to settle at room temperature for $1-2 \mathrm{~h}$. Controls contained $30 \mu \mathrm{l}$ of PBS instead of inhibitor solution.

\section{${ }^{125}$ I-labelled protein binding assay}

Fibronectin, collagen-I and lactoferrin were labelled with iodine according to a modified chloramine- $T$ method with Iodobeads [13]. The labelled proteins were kept at $4^{\circ} \mathrm{C}$ and used within 3 weeks. Radiolabelled proteins were diluted to $c .30000 \mathrm{cpm} / 50 \mu \mathrm{l}$ in PBS (pH 7.2) containing BSA $1 \%$ and added to $100 \mu \mathrm{l}$ of a bacterial cell suspension. After thorough mixing, samples were incubated at room temperature for $1 \mathrm{~h}$. The binding reaction was stopped by the addition of $2 \mathrm{ml}$ of ice-cold PBS containing Tween $20 \quad 0.1 \%$.
Supernates were aspirated after centrifugation at $3000 \mathrm{rpm}$ for $15 \mathrm{~min}$ and the radioactivity of the pellets was measured in a gamma-counter. For each experiment, negative control test tubes with all ingredients except bacteria were included and the radioactivity was determined. $S$. aureus strain Cowan I was used as a positive control.

\section{Electron microscopy}

Selected B. fragilis strains were incubated for $48 \mathrm{~h}$ in Wilkins-Chalgren anaerobic broth in an anaerobic jar, and on peptone yeast extract agar supplemented with horse blood $5 \%$. The bacteria were washed carefully in $0.02 \mathrm{M}$ phosphate buffer ( $\mathrm{pH}$. 6.8) and centrifuged at $1600 \mathrm{~g}$ for $15 \mathrm{~min}$. For examination of the bacterial cell surface structures by electron microscopy, negative staining with phosphotungstic acid $2 \%(\mathrm{pH} 7.2)$ for $1 \mathrm{~min}$ was used.

\section{Results}

\section{Influence of growth conditions on PAA}

In total, 65 anaerobic strains (Bacteroides, Prevotella, Fusobacterium, Peptostreptococcus and Clostridium) were grown on different media at different temperatures and were tested in PAA with latex particles coated with fibronectin or collagen-I (Table 1). Blood agar proved to be the optimal culture medium for anaerobes because only $34 \%$ of the strains displayed autoaggregation and the binding of the strains was stronger than when they were cultured in other media (brainheart infusion broth and agar, Wilkins-Chalgren broth). Incubation at $30^{\circ} \mathrm{C}$ or at $37^{\circ} \mathrm{C}$ made no difference to the binding of the strains.

\section{Binding of fibronectin, collagen-I and vitronectin to anaerobic bacteria in PAA}

Fifty-five Bacteroides isolates and 10 other anaerobic strains were examined with different proteins immobilised on latex beads (Tables 2 and 3). The binding of fibronectin and collagen-I was stronger to $B$. fragilis strains isolated from infections and from the faeces of healthy individuals than to strains of other Bacteroides species (Table 2). No significant differences were observed in the binding of the different proteins to the strains isolated from infections or from healthy

Table 1. Influence of culture medium on fibronectin and collagen binding of different anaerobic strains examined by PAA

\begin{tabular}{lccc}
\hline & \multicolumn{2}{c}{ Strains giving positive PAA (\%) with } & \multicolumn{1}{c}{$\begin{array}{c}\text { Strains } \\
\text { exhibiting }\end{array}$} \\
\cline { 2 - 3 } Culture medium & Fibronectin & Collagen-I & AA (\%) \\
\hline PY blood agar & 46 & 55 & 34 \\
BHI blood agar & 32 & 49 & 46 \\
BHI broth & 29 & 44 & 42 \\
Wilkins-Chalgren broth & 30 & 44 & 43 \\
\hline
\end{tabular}

AA, auto-agglutination; BHI, brain-heart infusion; PY, peptone yeast extract 
Table 2. Binding of Bacteroides strains to different ECM proteins investigated by the latex agglutination method

\begin{tabular}{|c|c|c|c|c|c|c|c|c|c|c|c|}
\hline \multirow[b]{3}{*}{ Species } & \multirow[b]{3}{*}{$\begin{array}{c}\text { Number of } \\
\text { strains }\end{array}$} & \multicolumn{9}{|c|}{ Number of strains that gave positive PAA reactions with } & \multirow[b]{3}{*}{ AA } \\
\hline & & \multicolumn{3}{|c|}{ Fibronectin } & \multicolumn{3}{|c|}{ Collagen-I } & \multicolumn{3}{|c|}{ Vitronectin } & \\
\hline & & $\begin{array}{c}+++ \\
++\end{array}$ & + & - & $\begin{array}{c}+++ \\
++\end{array}$ & + & - & $\begin{array}{c}+++ \\
++\end{array}$ & ++ & - & \\
\hline \multicolumn{12}{|l|}{ Abdominal infections } \\
\hline B. fragilis & 21 & 7 & 5 & 0 & 8 & 4 & 0 & 1 & 7 & 5 & 9 \\
\hline B. ovatus & 3 & 0 & 2 & 0 & 1 & 1 & 0 & 0 & 1 & 1 & 1 \\
\hline B. thetaiotaomicron & 1 & 0 & 0 & 1 & 0 & 1 & 0 & 0 & 0 & 1 & 0 \\
\hline B. multiacidus & 1 & 0 & 0 & 1 & 1 & 0 & 0 & 0 & 0 & 1 & 0 \\
\hline B. vulgatus & 1 & 0 & 0 & 0 & 0 & 0 & 0 & 0 & 0 & 0 & 1 \\
\hline Bacteroides spp. & 9 & 3 & 1 & 0 & 3 & 1 & 0 & 2 & 0 & 2 & 5 \\
\hline Total & 36 & 10 & 8 & 2 & 13 & 7 & 0 & 3 & 8 & 10 & 16 \\
\hline \multicolumn{12}{|c|}{ Faecal samples of healthy individuals } \\
\hline B. fragilis & 13 & 5 & 3 & 3 & 7 & 2 & 2 & 0 & 3 & 8 & 2 \\
\hline B. ovatus & 1 & 1 & 0 & 0 & 1 & 0 & 0 & 0 & 0 & 1 & 0 \\
\hline B. vulgatus & 2 & 0 & 1 & 0 & 0 & 1 & 0 & 0 & 0 & 2 & 0 \\
\hline Bacteroides spp. & 2 & 1 & 0 & 1 & 1 & 1 & 0 & 0 & 0 & 2 & 0 \\
\hline Total & 18 & 7 & 4 & 4 & 9 & 4 & 2 & 0 & 3 & 13 & 2 \\
\hline
\end{tabular}

AA, autoagglutination.

subjects. The binding of vitronectin was less common, but was never observed in the absence of fibronectin binding. Some of the anaerobic strains displayed agglutination with ovalbumin-coated beads, which is the reason why beads coated with BSA were used as a negative control.

Of the 10 other anaerobic strains, only one $C$. difficile strain gave a strong positive PAA reaction with beads coated with fibronectin, collagen-I or vitronectin. Collagen-I bound to a $P$. corporis isolate (Table 3 ).

Only 10 of the 65 anaerobic strains exhibited agglutination with mucin-coated beads. These were eight strains of $B$. fragilis, one of $P$. corporis and one of $C$. difficile. None of the strains examined bound to fetuin- or asialofetuin-coated beads.

\section{Inhibition of the binding of fibronectin and mucin in the PAA}

Fibronectin PAA was completely inhibited by preincubation of the bacterial suspension with soluble fibronectin $1 \mathrm{mg} / \mathrm{ml}$. Other glycoproteins or carbo- hydrates, such as sucralfate, suramin, fragmin, protamine, polylysine, dextran sulphate 500 , pentosan sulphate and heparin, did not inhibit the binding of fibronectin to the cells. Pre-incubation of the cells with mucin $1 \mathrm{mg} / \mathrm{ml}$ totally abolished the binding of mucin to the cells. Cell surface structures of $B$. fragilis and other anaerobic strains were sensitive to all proteases used (pronase $\mathrm{E}$, proteinase $\mathrm{K}$ and trypsin).

\section{Haemagglutination}

The ability of strains of $B$. fragilis and other Bacteroides spp. to agglutinate sheep and human red blood cells was examined. Twelve strains displayed a haemagglutination ability, whereas 43 strains did not agglutinate the red blood cells tested. All those strains that demonstrated a haemagglutination ability proved to be auto-aggregating strains, so the binding of fetuin and asialofetuin (the sialoproteins present on the erythrocyte membranes) to them could not be examined by the latex agglutination method. Those Bacteroides strains that haemagglutinated sheep or human red blood cells were investigated by electron microscopy to find pili responsible for the haemagglutination activity.

Table 3. Binding of different anaerobic strains to ECM proteins investigated by the latex agglutination method

\begin{tabular}{|c|c|c|c|c|c|c|c|c|c|c|c|}
\hline \multirow[b]{3}{*}{ Species } & \multirow[b]{3}{*}{$\begin{array}{c}\text { Number of } \\
\text { strains }\end{array}$} & \multicolumn{9}{|c|}{ Number of strains that gave positive PAA reactions with } & \multirow[b]{3}{*}{ AA } \\
\hline & & \multicolumn{3}{|c|}{ Fibronectin } & \multicolumn{3}{|c|}{ Collagen-I } & \multicolumn{3}{|c|}{ Vitronectin } & \\
\hline & & $\begin{array}{c}+++ \\
++\end{array}$ & + & - & $\begin{array}{c}+++ \\
++\end{array}$ & + & - & $\begin{array}{c}+++ \\
++\end{array}$ & + & - & \\
\hline C. difficile & 3 & 1 & 0 & 1 & 1 & 0 & 1 & 1 & 1 & 0 & 1 \\
\hline P. corporis & 2 & 0 & 0 & 1 & 1 & 0 & 0 & 0 & 0 & 1 & 1 \\
\hline P. prevotii & 3 & 0 & 0 & 3 & 0 & 3 & 0 & 0 & 0 & 3 & 0 \\
\hline F. nucleatum & 2 & 0 & 0 & 2 & 0 & 0 & 2 & 0 & 0 & 2 & 0 \\
\hline Total & 10 & 1 & 0 & 7 & 2 & 3 & 3 & 1 & 1 & 6 & 2 \\
\hline
\end{tabular}


After negative staining, no pilus-like structures were found on any strain tested.

\section{Binding of radiolabelled proteins to anaerobic bacteria}

The binding of ${ }^{125}$ I-labelled fibronectin, ${ }^{125} \mathrm{I}$-labelled collagen-I and ${ }^{125}$ I-labelled lactoferrin to all 65 anaerobic strains was tested. Only $29 \%$ of the strains bound to ${ }^{125} \mathrm{I}$-fibronectin. The binding of ${ }^{125} \mathrm{I}$-collagenI to the anaerobic strains was similar to that observed in the PAA; $70 \%$ of the strains showed a binding of $\geqslant 10 \%$ of the ${ }^{125} \mathrm{I}$-labelled collagen-I, in parallel with the strong $(+++)$ agglutination in the PAA. The binding of ${ }^{125}$ I-lactoferrin was extremely high (30-35\%) for six $B$ fragilis isolates (Fig. 1).

\section{Discussion}

An important early event in the development of many bacterial infections is the adherence of the pathogens to epithelial and endothelial cell surfaces. Connective tissue proteins such as collagen, laminin and serumderived fibronectin and vitronectin may all be involved in tissue colonisation in surgical and other infections [14]. The binding of fibronectin and collagen to different aerobic bacterial pathogens has been tested fairly frequently $[5,9,15]$. Far fewer data are available on the binding of vitronectin $[5,6,15]$. The binding of different matrix proteins to $S$. aureus and various coagulase-negative staphylococci has been investigated most frequently, which indicates the important role of these interactions in special infection processes $[9,16]$. The binding of ECM proteins to different bacterial cells may have a dual role in host-parasite interactions. The different cell-surface binding components specific for the various ECM proteins may be involved in the colonisation of wounds and other tissue lesions, but they may also aid indigenous flora such as lactobacilli in the vagina and $B$. vulgatus in the colon to establish themselves on mucosal surfaces $[5,17]$.

In the present study, the strains of different species of anaerobes exhibited different capacities to bind ECM proteins. Similarly as has already been shown for other bacterial species, different culture media and growth conditions influence the expression of cell surface proteins of anaerobic species. The growth of the strains on the surface of peptone yeast extract agar plates supplemented with horse blood provided the best conditions for the expression of surface binding structures by Bacteroides strains. $B$. fragilis is considered to be the most frequent pathogen involved in polymicrobial infections after abdominal surgery. The binding of different matrix proteins to $B$. fragilis strains, as demonstrated by means of PAA and the ${ }^{125}$ I-labelled protein binding assay, suggests that specific binding may be implicated in the adherence of these strains to epithelial surfaces, similar to the processes observed with other pathogens $[9,15,18-$ 20]. The results of this study indicate that Bacteroides

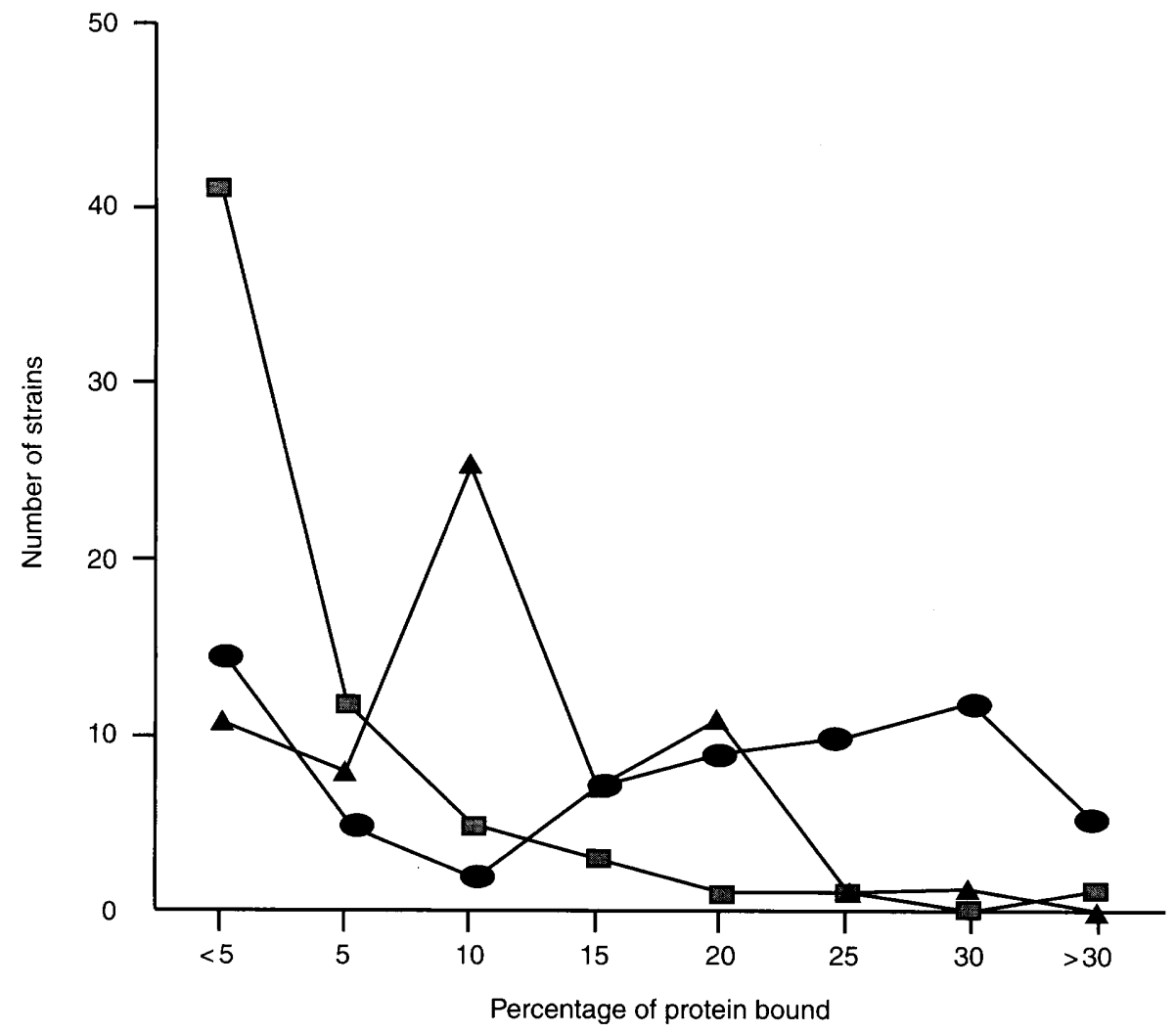

Fig. 1. Binding of anaerobic bacteria to ${ }^{125}$ I-labelled matrix proteins: $;$, fibronectin; $\boldsymbol{\Delta}$, collagen-I; $\boldsymbol{O}$, lactoferrin. 
strains contain components that recognise fibronectin and collagen type-I (both immobilised and soluble forms), which can all bind effectively to members of the Bacteroides genus. Protease treatment of bacterial cells resulted in complete loss of the reactivity to fibronectin-PAA, which indicates the proteinaceous nature of the respective cell surface receptors. All strains which were isolated from infective processes and did not exhibit auto-aggregation adhered to fibronectin and collagen-I in the PAA. Sixty-one and $69 \%$ of the $B$. fragilis strains isolated from faeces also had binding components for fibronectin and collagenI, respectively. On the other hand, B. vulgatus strains, much less frequently involved in infective processes, were also found to possess a binding component for fibronectin. This means that the adherence of Bacteroides spp. to fibronectin and to other ECM proteins is not necessarily connected with their pathogenicity, but may be the critical step for tissue invasion, especially if the adherence event induces other reactions, possibly leading to the degradation of basement membranes.

Lactoferrin is an iron-binding glycoprotein secreted by glandular epithelial cells and present in the serum and on mucosal surfaces. It has been suggested that lactoferrin, having a high affinity for iron, removes this element from the iron-dependent metabolic processes of certain micro-organisms, thereby causing an antibacterial effect. On the other hand, the capacity of bacteria to bind lactoferrin may be correlated with virulence [21]. This study revealed a high level of binding of ${ }^{125}$ I-lactoferrin to anaerobic bacteria, and especially those Bacteroides strains isolated from infective processes or from the faeces of healthy individuals. Further studies are needed to determine whether the lactoferrin binding of Bacteroides strains may be of importance in infective processes.

This study was supported by grants from the Swedish Medical Research Council $(16 \times 04723)$ and grants from NUTEK to Professor T. Wadstrom.

\section{References}

1. Finegold SM, Lance WG. Anaerobes in human disease. San Diego, Academic Press. 1989.

2. Onderdonk AB, Kasper DL, Cisneros RL, Bartlett JG. The capsular polysaccharide of Bacteroides fragilis as a virulence factor: comparison of the pathogenic potential of encapsulated and unencapsulated strains. $J$ Infect Dis 1977; 136: 82-89.
3. Brook I, Myhal ML. Adherence of Bacteroides fragilis group species. Infect Immun 1991; 59: 742-744.

4. Pruzzo C, Guzmán CA, Dainelli B. Incidence of hemagglutination activity among pathogenic and non-pathogenic Bacteroides fragilis strains and role of capsule and pili in HA and adherence. FEMS Microbiol Lett 1989; 59: 113-118.

5. Nagy E, Manncke B, Werner H. Fibronectin and vitronectin binding of Bacteroides fragilis and eight other species of the genus. Int $J$ Med Microbiol Virol Parasitol Infect Dis 1994; 281: $235-239$

6. Eiring P, Manncke B, Gebracht K, Werner H. Bacteroides fragilis adheres to laminin significantly stronger than Bacteroides theteiotaomicron and other species of the genus. Int $J$ Med Microbiol Virol Parasitol Infect Dis 1995; 282: 279286.

7. Labat-Robert J, Bihari-Varga M, Robert L. Extracellular matrix. FEBS Lett 1990; 268: 386-393.

8. Wadström T. Microbial lectins Escherichia coli (ETEC) and Campylobacter pylori. Lectins biology biochemistry clinical biochemistry, vol 8. Hellerup, Denmark, Textop. 229-234.

9. Naidu AS, Paulsson M, Wadström T. Particle agglutination assay for rapid detection of fibronectin, fibrinogen and collagen receptors on Staphylococcus aureus. J Clin Microbiol 1988; 26: 1549-1554.

10. Griffiths E. The iron uptake systems of pathogenic bacteria. Molecular, physiological and clinical aspects. Iron and Infection 1987: 69-137.

11. Lindahl $M$, Brossmer $R$, Wadström $T$. Sialic acid and Nacetylgalactoseamine specific bacterial lectins of enterotoxigenic Escherichia coli. The molecular immunology of complex carbohydrates. New York, Plenum Press. 1988: 123-152.

12. Vuento $M$, Vaheri A. Purification of fibronectin from human plasma by affinity chromatography under non-denaturing conditions. Biochem J 1979; 183: 331-337.

13. Markwell MAK. A new solid state reagent to iodinate proteins. I. Conditions of the efficient labelling of antiserum. Anal Biochem 1982; 125: 427-432.

14. Vercelotti GM, McCarthy JB, Lindholm P, Peterson PK, Jacob HS, Furcht LT. Extracellular matrix proteins (fibronectin, laminin, and type-IV collagen) bind and aggregate bacteria. Am J Pathol 1985; 120: 13-21.

15. Paulsson M, Wadström T. Vitronectin and type-I collagen binding by Staphylococcus aureus and coagulase-negative staphylococci. FEMS Microbiol Immunol 1990; 2: 55-62.

16. Paulsson $M$, Ljungh $\AA$, Wadström T. Rapid identification of fibronectin, vitronectin, laminin, and collagen cell surface binding proteins on coagulase-negative staphylococci by particle agglutination assays. J Clin Microbiol 1992; 30: 2006-2012.

17. Nagy E, Fröman G, Mardh P-A. Fibronectin binding of Lactobacillus species isolated from women with and without bacterial vaginosis. J Med Microbiol 1992; 37: 38-42.

18. Switalski LM, Ljungh A, Ryden $C$, Rubin $K$, Höök $M$, Wadström T. Binding of fibronectin to the surface of group A, $\mathrm{C}$ and $\mathrm{G}$ streptococci isolated from human infections. Eur $J$ Clin Microbiol 1982; 1: 381-387.

19. Fröman G, Switalski LM, Faris A, Wadström T, Höök M. Binding of Escherichia coli to fibronectin. A mechanism of tissue adherence. J Biol Chem 1984; 259: 14899-14905.

20. Baloda SB, Faris A, Fröman G, Wadström T. Fibronectin binding to Salmonella strains FEMS Microbiol Lett 1985; 28: $1-5$.

21. Schryvers AB, Gonzalez GC. Comparison of the abilities of different protein sources of iron to enhance Neisseria meningitidis infection in mice. Infect Immun 1989; 57: 24252429 . 